\title{
PRAKTYCZNE PROBLEMY ZAJĘCIA WIERZYTELNOŚCI Z RACHUNKU BANKOWEGO W ADMINISTRACYJNYM POSTĘPOWANIU EGZEKUCYJNYM
}

\begin{abstract}
Abstrakt: Celem niniejszej pracy jest przedstawienie najczęściej wybieranego w praktyce sposobu egzekucji świadczeń pieniężnych, jakim jest egzekucja z wierzytelności wynikającej z rachunku bankowego. Opracowanie rozpoczęto od omówienia pojęcia, istoty i regulacji prawnej rachunku bankowego oraz zarysowano podstawę prawną egzekucji z rachunków bankowych. W artykule zanalizowano przebieg postępowania egzekucyjnego, skutki zajęcia rachunku oraz ograniczenia egzekucyjne, stosując formalno-dogmatyczną metodę pracy nad zagadnieniem egzekucji z rachunku bankowego. Wyszczególniono zagadnienia problematyczne zarówno na płaszczyźnie teoretycznej, jak i praktycznej. Odwołano się też do aktualnego dorobku doktryny i judykatury. Praca uwzględnia stan prawny przepisów obowiązujący na chwilę jej przygotowania oraz uchwaloną nowelizację wchodzącą w życie z dniem 19 lutego 2021 roku.
\end{abstract}

Słowa kluczowe: rachunek bankowy, przedmiot egzekucji, egzekucja z rachunku bankowego, umorzenie postępowania, doręczenie

\section{POJĘCIE ORAZ CEL POSTĘPOWANIA EGZEKUCYJNEGO I EGZEKUCJI ADMINISTRACYJNEJ}

Administracyjne postępowanie egzekucyjne ${ }^{1}$ jest to prowadzone przez organy egzekucyjne postępowanie i stosowanie przez nie środków przymusu służących doprowadzeniu do wykonania lub zabezpieczenia wykonania obowiązków publicznoprawnych. Poza zakresem postępowania egzekucyjnego pozostaje postępowanie wierzyciela - stanowi ono etap czynności przedegzekucyjnych ${ }^{2}$. Postępowanie egzekucyjne zaliczane jest do grupy procedur wykonawczych. Ma za zadanie zapewnić posłuch obowiązkom wynikającym $\mathrm{z}$ aktów indywidualnych

1 Art. 1 pkt 2 ustawy z dnia 17 czerwca 1966 r. o postępowaniu egzekucyjnym w administracji, tekst jedn. Dz.U. z 2020 r. poz. 1427 (dalej: u.p.e.a., ustawa egzekucyjna).

2 Art. 1 pkt $1 \mathrm{w}$ zw. $\mathrm{z}$ art. $15 \S 1$ u.p.e.a. 
albo generalnych. W literaturze prawa egzekucyjnego odróżnia się postępowanie egzekucyjne od egzekucji administracyjnej:

Postępowanie egzekucyjne jest prawnie zorganizowanym ciągiem czynności organu egzekucyjnego i innych podmiotów, mającym na celu urzeczywistnienie konkretnej normy prawnej, ustalonej w tytule egzekucyjnym ${ }^{3}$, przy zastosowaniu prawnych środków przymusu. Egzekucja oznacza zastosowanie przez powołane organy egzekucyjne środków przymusu państwowego w celu wykonania obowiązku określonego w tytule egzekucyjnym. Pojęcie „postępowanie egzekucyjne” wskazuje na aspekt procesowy stosowania przymusu egzekucyjnego, natomiast pojęcie ,egzekucja administracyjna" - na jego aspekt materialny ${ }^{4}$.

Postępowanie egzekucyjne jest ciągiem czynności procesowych i egzekucyjnych. Egzekucja administracyjna, będąc jedynie stadium czynności wykonawczych, jest ciągiem czynności egzekucyjnych ${ }^{5}$.

Dla dalszych rozważań istotne jest określenie momentu wszczęcia postępowania egzekucyjnego i egzekucji administracyjnej. Przepisy administracyjnej ustawy egzekucyjnej obowiązujące do dnia 19 lutego 2021 roku nie wskazywały expressis verbis daty wszczęcia. W dodatku niekonsekwentnie posługiwały się terminami „egzekucja administracyjna” i ,postępowanie egzekucyjne”. W literaturze i orzecznictwie wypracowano pogląd, że wszczęcie postępowania egzekucyjnego następowało na wniosek wierzyciela i na podstawie wystawionego przez niego tytułu wykonawczego (art. $26 \S 1$ u.p.e.a.), a gdy wierzyciel był jednocześnie organem egzekucyjnym - wszczynał on postępowanie z urzędu na podstawie tytułu wykonawczego przez siebie wystawionego (art. $26 \S 4$ u.p.e.a.). W przypadku, o którym mowa w art. $26 \S 1$ u.p.e.a (przy braku tożsamości podmiotowej organu egzekucyjnego i wierzyciela), datą wszczęcia postępowania egzekucyjnego był dzień doręczenia organowi egzekucyjnemu tych dokumentów przez wierzyciela. Gdy zachodziła tożsamość organu egzekucyjnego i wierzyciela (art. $26 \S 4$ u.p.e.a.), to datą wszczęcia postępowania egzekucyjnego był dzień sporządzenia tytułu wykonawczego przez wierzyciela, będącego jednocześnie organem egzekucyjnym $^{6}$. Od 20 lutego 2021 roku $^{7}$ moment wszczęcia postępowania egzekucyjnego jest określony wprost $\mathrm{w}$ art. $26 \S 3 \mathrm{a}$ u.p.e.a. Zgodnie $\mathrm{z}$ tym przepisem wszczęcie postępowania egzekucyjnego następuje z chwilą:

3 Tytuł egzekucyjny to materialnoprawna podstawa prawna egzekucji administracyjnej, na przykład decyzja administracyjna, deklaracja.

${ }^{4}$ L. Klat-Wertelecka, Egzekucja administracyjna w praktyce, Gdańsk 2013, s. 21; zob. eadem, Pojęcie postępowania egzekucyjnego $w$ administracji a pojęcie egzekucji administracyjnej, „Opolskie Studia Administracyjno-Prawne" 2011, z. 9, s. 11-24.

5 Pod pojęciem czynności egzekucyjnych rozumie się wszelkie podejmowane przez organ egzekucyjny działania zmierzające do zastosowania lub zrealizowania środka egzekucyjnego art. 1a pkt 2 u.p.e.a.

${ }^{6}$ L. Klat-Wertelecka, Egzekucja..., s. 92; wyrok Wojewódzkiego Sądu Administracyjnego w Szczecinie z dnia 4 listopada 2015 r., I SA/Sz 960/15, Legalis nr 1390447; wyrok SN z dnia 3 marca 2011 r., II UK 307/10, LEX nr 785627.

7 Art. 26 § 3a u.p.e.a. został dodany ustawą z dnia 4 lipca 2019 roku o zmianie ustawy o postępowaniu egzekucyjnym w administracji oraz niektórych innych ustaw, Dz.U. z 2019 r. poz. 1553. 
1. doręczenia wniosku o wszczęcie egzekucji administracyjnej i tytułu wykonawczego organowi egzekucyjnemu, jeżeli wierzyciel nie jest jednocześnie organem egzekucyjnym,

2. nadania tytułowi wykonawczemu klauzuli o skierowaniu tego tytułu do egzekucji administracyjnej, jeżeli wierzyciel jest jednocześnie organem egzekucyjnym,

3. wystawienia tytułu wykonawczego w przypadku przekształcenia zajęcia zabezpieczającego w zajęcie egzekucyjne.

Nastąpiła zatem zmiana w określaniu momentu wszczęcia administracyjnego postępowania egzekucyjnego w sytuacji tożsamości wierzyciela i organu egzekucyjnego.

Wszczęcie egzekucji przed 30 lipca 2020 roku następowało z chwilą ,,doręczenia zobowiązanemu odpisu tytułu wykonawczego lub doręczenia dłużnikowi zajętej wierzytelności zawiadomienia o zajęciu wierzytelności lub innego prawa majątkowego, jeżeli to doręczenie nastąpiło przed doręczeniem zobowiązanemu odpisu tytułu wykonawczego" (art. $26 \S 5$ u.p.e.a.). Od 30 lipca 2020 roku $^{8}$ art. 26 $\S 5$ u.p.e.a. przewiduje dodatkowo, że wszczęcie egzekucji następuje z chwilą:

podpisania protokołu zajęcia ruchomości przez pracownika obsługującego organ egzekucyjny, jeżeli to podpisanie nastąpiło przed doręczeniem zobowiązanemu odpisu tytułu wykonawczego; wpisu w księdze wieczystej o wszczęciu egzekucji z nieruchomości lub złożenia wniosku o wpis o wszczęciu egzekucji z nieruchomości do zbioru dokumentów, jeżeli ten wpis lub to złożenie nastąpiło przed doręczeniem zobowiązanemu odpisu tytułu wykonawczego.

Głównym celem postępowania egzekucyjnego jest przymusowe doprowadzenie do wykonania obowiązku o charakterze publicznoprawnym. Za cel egzekucji administracyjnej uznaje się wykonanie obowiązków wynikających z decyzji lub postanowień właściwych organów, lub bezpośrednio z przepisów prawa, jeżeli należą do właściwości organów administracji rządowej lub jednostek samorządu terytorialnego ${ }^{9}$. Dla zrealizowania celu postępowania egzekucyjnego konieczne jest zastosowanie określonych w u.p.e.a. środków egzekucyjnych.

\section{NORMATYWNE PODSTAWY ZAJĘCIA WIERZYTELNOŚCI Z RACHUNKU BANKOWEGO}

Katalog środków egzekucyjnych w postępowaniu egzekucyjnym należności pieniężnych zawarty jest $\mathrm{w}$ art. la pkt 12 lit. a u.p.e.a. Jednym $\mathrm{z}$ nich jest egzekucja $\mathrm{z}$ rachunków bankowych i wkładów oszczędnościowych. Z tytułu umowy rachunku bankowego, bank jest dłużnikiem posiadacza rachunku (zobowiązane-

8 Zmiana została wprowadzona ustawą z dnia 11 września 2019 roku o zmianie ustawy o postępowaniu egzekucyjnym w administracji oraz niektórych innych ustaw, Dz.U. z 2019 r. poz. 2070 ze zm.

9 L. Klat-Wertelecka, Egzekucja ..., s. 24. 
go w egzekucji administracyjnej), który ma wierzytelność (roszczenie) o zwrot określonej sumy środków pieniężnych. Omawiana wierzytelność podlega więc egzekucji administracyjnej ${ }^{10}$.

Przepisy ogólne odnoszące się do stosowania środków egzekucyjnych w egzekucji należności pieniężnych zawarto w dziale II, rozdz. 1 u.p.e.a. Przyjęto w tym zakresie konstrukcję objawiającą się w obowiązku zawiadomienia dłużnika zajętej wierzytelności ${ }^{11}$ o zajęciu (art. 67 § 1 u.p.e.a.). $Z$ chwilą doręczenia trzeciodłużnikowi tego zawiadomienia następuje zastosowanie środka egzekucyjnego. Odnośnie do egzekucji z rachunku bankowego świadczy o tym art. $80 § 2$ u.p.e.a. Wysokość przedmiotowego zajęcia jest sumą egzekwowanej należności pieniężnej wraz z odsetkami z tytułu niezapłacenia w terminie dochodzonej wierzytelności oraz kosztów egzekucyjnych (art. $80 \S 1$ u.p.e.a.). Co do prowadzenia egzekucji, w ramach której nastąpiło zajęcie wierzytelności z rachunków bankowych, zobowiązany zostaje ograniczony w prawie udzielania zleceń rozliczeń pieniężnych, niemniej jednak tylko do wysokości należności podlegających egzekucji. Rachunek bankowy pozostaje otwarty, a zobowiązany może dysponować swobodnie nadwyżką ponad zajętą kwotę ${ }^{12}$. „Organ egzekucyjny »dysponuje« jedynie kwotą podlegającą egzekucji"13. Zajęcie obejmowało wyłącznie kwoty zgromadzone na rachunku bankowym w chwili zajęcia, jak również te, które nie były na rachunku bankowym w chwili zajęcia, a zostały wpłacone na ten rachunek po jego dokonaniu (art. $80 \S 2$ u.p.e.a.). Taka konstrukcja przepisu pomijała praktykę będącą próbą ucieczki od skutecznej egzekucji, polegającą na otwieraniu przez zobowiązanych $\mathrm{w}$ banku realizującym zajęcie wierzytelności $\mathrm{z}$ rachunku bankowego nowych rachunków (już po dokonaniu zajęcia). W takim przypadku organ egzekucyjny musiał dokonać kolejnego zajęcia w tym banku, co wymagało dodatkowych czynności poszukiwania majątku oraz wiązało się z naliczaniem kolejnych wydatków związanych z doręczeniem zawiadomień o zajęciu, które ponosił zobowiązany (zob. art. 64b u.p.e.a.). Tym samym od 30 października 2020 roku zajęcie obejmuje również kwoty, które zostały wpłacone na inny rachunek, otwarty po dokonaniu zajęcia (art. $80 \S 2$ pkt 2 u.p.e.a.). O zajęciu wierzytelności z rachunku bankowego należy poinformować również zobowiązanego, na co wskazuje art. $80 \S 3$ u.p.e.a.

Jednocześnie z przesłaniem do banku zawiadomienia o zajęciu wierzytelności pieniężnej zobowiązanego z rachunku bankowego, organ egzekucyjny zawiadamia zobowiązanego o zajęciu jego

10 E. Niezbecka, Egzekucja administracyjna z rachunków bankowych, [w:] System egzekucji administracyjnej, red. J. Niczyporuk, S. Fundowicz, J. Radwanowicz, Lublin 2004, s. 339.

11 Pod pojęciem dłużnika zajętej wierzytelności (inaczej: trzeciodłużnika) rozumie się dłużnika zobowiązanego, jak również bank, pracodawcę, podmiot prowadzący działalność maklerską, trasata oraz inne podmioty realizujące, na wezwanie organu egzekucyjnego, zajęcie wierzytelności lub innego prawa majątkowego zobowiązanego (art. la pkt 3 u.p.e.a.).

12 Wyrok WSA w Warszawie z dnia 19 listopada 2007 r., III SA/Wa 1462/07, LEX nr 494247.

13 M. Karpiuk, Egzekucja administracyjna z rachunków bankowych, „Glosa” 2014, nr 4, s. 101. 
wierzytelności z rachunku bankowego, doręczając mu odpis tytułu wykonawczego, o ile nie został wcześniej doręczony, i odpis zawiadomienia skierowanego do banku o zakazie wypłaty zajętej kwoty z rachunku bankowego bez zgody organu egzekucyjnego.

Użycie w art. $80 \S 3$ u.p.e.a. pojęcia ,zawiadomienie skierowane do banku" określa kolejność działań podejmowanych przez organ egzekucyjny, zatem najpierw kieruje się zawiadomienie do banku, a następnie do zobowiązanego ${ }^{14}$. Kolejność ta jest $\mathrm{w}$ tym przypadku uzasadniona szczególnym rodzajem czynności egzekucyjnej i możliwością szybkiego podjęcia gotówki z rachunku bankowego, w celu udaremnienia egzekucji ${ }^{15}$. „Ustawodawca nie wprowadza zasady, według której zobowiązany miałby wcześniej, ewentualnie jednocześnie z bankiem, otrzymać zawiadomienie o zajęciu wierzytelności pieniężnej”16. Należy pamiętać, że oprócz doręczenia zawiadomienia o zajęciu, konieczne jest doręczenie zobowiązanemu również odpisu tytułu wykonawczego. Wprawdzie może ono nastąpić później niż doręczenie zawiadomienia o zajęciu do banku, jednakże „Niedoręczenie tytułu wykonawczego oznacza, że egzekucja nie została wszczęta, czego następstwem jest $z$ kolei brak podstaw prawnych do podejmowania jakichkolwiek działań, które mogą być podejmowane wyłącznie w toku postępowania egzekucyjnego" 17 . W literaturze i orzecznictwie można jednak odnaleźć poglądy stojące w opozycji do zaprezentowanego stanowiska. Głoszą one, że: „Fakt niewłaściwego doręczenia odpisów tytułów wykonawczych i zawiadomienia o zajęciu pozostaje bez wpływu na kwestię umorzenia prowadzonego wobec zobowiązanego postępowania egzekucyjnego"18.

Na organie egzekucyjnym nie ciąży obowiązek wskazywania numeru rachunku bankowego. „Otrzymanie przez bank zawiadomienia o zajęciu wierzytelności z rachunku bankowego zobowiązanego bez wskazania numeru rachunku skutkuje zajęciem wszystkich rachunków bankowych tego zobowiązanego w danej jednostce organizacyjnej banku"19. Co więcej, zajęcie wierzytelności jest skuteczne w odniesieniu do rachunku bankowego prowadzonego dla kilku osób fizycznych, którego współposiadaczem jest zobowiązany (art. $81 \S 1$ la u.p.e.a.). Jeżeli zobowiązanym jest jednostka budżetowa, zajęciu podlega wyłącznie rachunek wydatków (art. $81 \S 2$ u.p.e.a.). W celu gospodarnego prowadzenia egzekucji przyjęto rozwiązanie nakazujące w pierwszej kolejności zaspokojenie organu egzekucyj-

14 Wyrok WSA w Gorzowie Wielkopolskim z dnia 1 grudnia 2011 r., I SA/Go 1015/11, LEX nr 1133480.

15 Wyrok NSA z dnia 22 grudnia 1999 r., III SA 8330/98, LEX nr 47238.

16 M. Karpiuk, op. cit., s. 100.

17 Wyrok WSA w Gliwicach z dnia 3 września 2019 r., I SA/G1 321/19, LEX nr 2724647.

18 Wyrok WSA w Poznaniu z dnia 4 stycznia 2012 r., I SA/Po 288/11, Legalis nr 482268; zob. P.M. Przybysz, art. 26, [w:] idem, op. cit., LEX 2021; zob. wyrok WSA w Warszawie z dnia 22 października 2014 r., V SA/Wa 1286/14, Legalis nr 1915754.

19 W. Piątek, A. Skoczylas, Egzekucja z rachunków bankowych i wkładów oszczędnościowych, [w:] System Prawa Administracyjnego, t. 9. Prawo procesowe administracyjne, red. R. Hauser, Z. Niewiadomski, A. Wróbel, Warszawa 2020, s. 608. 
nego i wierzyciela $\mathrm{z}$ rachunków bankowych zobowiązanego, innych niż lokata terminowa. Pozwala to uniknąć między innymi straty jej oprocentowania (art. 81 $\S 3$ u.p.e.a.). Konstrukcja niektórych rachunków bankowych zawiera w sobie możliwość spowodowania tak zwanego salda debetowego. Należy uznać, że ani organ egzekucyjny, ani wierzyciel nie mogą się domagać z niego zaspokojenia ${ }^{20}$. Co więcej, jeżeli saldo takie jest ujemne, to kwoty wpływające na rachunek zadłużonego w banku nie podlegają przekazaniu na rachunek organu egzekucyjnego, ponieważ jedynie zmniejszają ujemne saldo debetowe. W zależności od treści umowy bank może potrącić $\mathrm{z}$ rachunku bieżące koszty prowadzenia rachunku ${ }^{21}$.

Skutki zajęcia rachunku bankowego są kwalifikowane przez zobowiązanego zazwyczaj jako dolegliwe. Dochodzi bowiem do wstrzymania przez bank wszelkich wypłat z zajętego rachunku (art. 86a § 1 u.p.e.a.) z wyjątkiem kwot wolnych od egzekucji (zob. art. 54 pr.bank. ${ }^{22}$ ), środków wyłączonych spod egzekucji ${ }^{23}$, a także wypłat na bieżące wynagrodzenia za pracę oraz na zasądzone alimenty i renty o charakterze alimentacyjnym, zasądzone tytułem odszkodowania" (art. 81 $\S 4$ u.p.e.a.). Tę regułę ,stosuje się również do podatku dochodowego od osób fizycznych oraz składek na ubezpieczenie społeczne, należnych od dokonywanych wypłat na bieżące wynagrodzenia" (art. $81 \S 4$ u.p.e.a.). Ponadto na skutek zajęcia rachunku bankowego zachodzi konieczność poniesienia kosztów egzekucyjnych przewidzianych ustawą egzekucyjną, ale nie tylko. W zależności od umowy banki pobierają prowizje i opłaty w związku z realizacją zajęcia lub przekazywaniem dochodzonych kwot do organu egzekucyjnego ${ }^{24}$.

20 W. Zręda, Administracyjne zajęcie rachunku bankowego, „Prawo Bankowe” 2002, nr 3, s. 58.

${ }^{21}$ E. Niezbecka, op. cit., s. 343; na temat prawa potrącenia zob. art. 498 n. k.c.

22 Ustawa z dnia 29 sierpnia 1997 roku Prawo bankowe, tekst jedn. Dz.U. z 2019 r. poz. 2357 ze zm.

23 Jako przykład można podać świadczenia, o których mowa w art. 8, art. 8a, art. 10 § 4 i 5 u.p.e.a. Należy zaznaczyć, że wyłączenie od zajęcia określonych środków pieniężnych ciąży na banku. Nie jest bowiem rolą organu egzekucyjnego weryfikowanie źródeł pochodzenia podlegających zajęciu środków - wyrok NSA z dnia 31 stycznia 2019 r., II FSK 3034/18, LEX nr 2656931.

24 Tytułem przykładu: w Santander Bank Polska SA za przyjęcie do realizacji zajęcia egzekucyjnego/zabezpieczającego z rachunku bankowego (za każde zajęcie) pobiera się $30 \mathrm{zl}$, natomiast za realizację zajęcia egzekucyjnego/zabezpieczającego - 60 zł. Wyłączone są kwoty mniejsze niż 30 zł. Powyższe stawki dotyczą czynności bankowych dla firm, https://toip-firmy.santander.pl/produkt/inne-oplaty-i-prowizje (dostęp: 24.10.2020); w mBanku SA opłata za przelew środków pieniężnych na rachunek wskazany przez organ egzekucyjny w zajęciu egzekucyjnym wynosi $30 \mathrm{zł,}$ na co wskazuje taryfa prowizji i opłat bankowych dla osób fizycznych w ramach bankowości detalicznej mBanku SA obowiązująca od 30 lipca 2020 roku — https://pdf.mbank.pl/mbankpl/of/tpio/ taryfa-osobyfiz-30-07-2020.pdf (dostęp: 24.10.2020). Warto wskazać w tym miejscu na wyrok, w którym uznając za niedozwolone postanowienia wzorca umowy pod postacią: „Realizacja tytułu wykonawczego przez Bank - 15,00 zł.” sąd uznał, że stanowi ono nadużycie przewagi kontraktowej banku, jako profesjonalisty względem konsumenta, przyznając bankowi przewagę w łączącym ich stosunku umownym - wyrok SO w Warszawie z dnia 09 stycznia 2012 roku, XVII AmC 375/11, LEX nr 2545366. 


\section{ASYMETRIA INFORMACJI I OCZEKIWAŃ MIĘDZY ORGANEM EGZEKUCYJNYM A ZOBOWIĄZANYM}

Stosowanie jakichkolwiek środków egzekucyjnych stanowi dolegliwość dla zobowiązanego. Do zawiązania węzła egzekucyjnego między nim a wierzycielem i organem egzekucyjnym może dojść z różnych powodów. Brak dobrowolnego wykonania obowiązku publicznoprawnego może wynikać ze świadomego działania, ale nie można wykluczać roztargnienia po stronie zobowiązanego, przejawiającego się na przykład w przeświadczeniu o dopełnieniu obowiązku bądź zapomnieniu o nim. Przyczyny mogą przyjmować także charakter obiektywny, pod postacią rzeczywistego braku możliwości spełnienia obowiązków, chociażby ze względu na niedysponowanie wystarczającą ilością środków finansowych bez uszczerbku w zaspokojeniu podstawowych potrzeb życiowych swoich i najbliższej rodziny.

$\mathrm{Na}$ mocy odesłania $\mathrm{z}$ art. 18 u.p.e.a. w postępowaniu egzekucyjnym stosuje się odpowiednio przepisy k.p.a. ${ }^{25}$, w tym art. 9, stanowiący normatywne odbicie zasady informowania. W postępowaniu administracyjnym przyjmuje się, że strona, której transformacja w zobowiązanego następuje na etapie postępowania wykonawczego, nie powinna ponosić szkody z powodu nieznajomości prawa. Toteż już na etapie postępowania orzeczniczego organy administracji publicznej pouczają stronę, że niewykonanie obowiązku będzie podlegało realizacji w trybie przepisów o postępowaniu egzekucyjnym w administracji. Analogiczne pouczenie znajduje się w drukach deklaracji, z których wynika obowiązek (art. 3a § 2 pkt 1 u.p.e.a.). Nawet odnośnie do obowiązków wynikających z mocy prawa, takich jak opłata za parkowanie w strefie płatnego parkowania, pojawia się informacja o konieczności jego wykonania, choćby na parkometrze, znakach drogowych. Stosowne informacje można odnaleźć niekiedy również w prasie, mediach, alertach RCB (na przykład o obowiązkach w związku z pandemią COVID-19). Już w tym momencie obywatel styka się z informacją o ciążących na nim obowiązkach. Częstokroć jednak nie powoduje to zmiany jego świadomości. W razie niewykonania powinności, mimo że termin jej wykonalności nadszedł, do zobowiązanego wysyłane są kolejne komunikaty pod postacią fakultatywnych działań informacyjnych wierzyciela, niegenerujące jeszcze dodatkowych kosztów (art. $6 \S 1$ b u.p.e.a.) lub obligatoryjnego przesłania do zobowiązanego upomnienia (art. 15 § 1 u.p.e.a), którego koszt od 13 października 2021 roku wynosi 16 zł $^{26}$. W ostatnim przypadku niejednokrotnie dochodzi do aktywizacji zobowiązanego. Dociera do niego bowiem nie tylko wiadomość o zagrożeniu skierowania sprawy na drogę postępowania egzekucyjnego, ale również o wygenerowaniu przez upomnienie dodatkowej

${ }^{25}$ Ustawa z dnia 14 czerwca 1960 roku - Kodeks postępowania administracyjnego, tekst jedn. Dz.U. z 2020 r. poz. 256 ze zm.

26 Rozporządzenie Ministra Finansów, Funduszy i Polityki Regionalnej z dnia 5 stycznia 2021 r. w sprawie wysokości kosztów upomnienia doręczanego zobowiązanemu przed wszczęciem egzekucji administracyjnej, Dz.U. poz. 67, § 1 . 
należności do zapłaty. Mobilizacja ta przejawia się zazwyczaj na dwa sposoby: 1. zarzucaniu bezprawności działania wierzyciela i podnoszeniu zastrzeżenia nieistnienia obowiązku, 2. wykonaniu obowiązku.

Niekiedy, mimo przekazania informacji o nieuchronności zastosowania środków egzekucyjnych w razie braku dobrowolnego wykonania obowiązku, bierność zobowiązanego pozostaje niezmienna. Właśnie wtedy dochodzi często do asymetrii informacji, rozumianej nie jako jej niedostarczenie zobowiązanemu, lecz jako nierównowaga między informacjami o toczącym się postępowaniu egzekucyjnym i zastosowaniu środka egzekucyjnego, jakimi dysponują organ egzekucyjny, wierzyciel i bank, a informacjami w tym zakresie, jakie posiadł w danej chwili zobowiązany.

Moment, w którym wierzyciel i organ egzekucyjny wchodzą w posiadanie informacji o wszczęciu postępowania egzekucyjnego, różni się w zależności od tego, czy zachodzi między nimi tożsamość podmiotowa. Jeśli tak, to w ujęciu prawnym zarówno organ egzekucyjny, jak i wierzyciel dowiadywali się o wszczęciu postępowania egzekucyjnego w chwili sporządzenia tytułu wykonawczego (od 20 lutego 2021 roku w momencie nadania tytułowi wykonawczemu klauzuli o skierowaniu tego tytułu do egzekucji administracyjnej). Faktycznie, jeżeli urząd obsługujący organ ma wyodrębnione komórki organizacyjne wierzyciela i organu egzekucyjnego, to należy uwzględnić opóźnienie w przesłaniu informacji związane z komunikacją między nimi. Trzeba jednak pamiętać, że ani utrwalone zwyczaje ani struktura organizacyjna urzędu nie mają wpływu na kształt unormowań prawnych. Jeżeli tożsamość między wierzycielem a organem egzekucyjnym nie zachodzi, to informację o wszczęciu postępowania egzekucyjnego organ egzekucyjny otrzymuje w momencie doręczenia wniosku o wszczęcie egzekucji oraz tytułu wykonawczego, natomiast wierzyciel w momencie otrzymania potwierdzenia doręczenia pism inicjujących postępowanie. Zobowiązany na tym etapie nie posiadł jeszcze informacji o toczącym się wobec niego postępowaniu egzekucyjnym.

Chwilą, w której organ egzekucyjny i bank uzyskują informację o zastosowaniu środka egzekucyjnego pod postacią zajęcia wierzytelności z rachunku bankowego, jest doręczenie bankowi zawiadomienia o zajęciu wierzytelności pieniężnej zobowiązanego $\mathrm{z}$ rachunku bankowego (art. 80 § 2 u.p.e.a.). Organ egzekucyjny doręcza bankowi zawiadomienie o zajęciu zgodnie z dyspozycją art. 86 b u.p.e.a., czyli, co do zasady, przy wykorzystaniu systemu teleinformatycznego Ognivo obsługującego zajęcie wierzytelności z rachunku bankowego, o którym mowa w art. 112c pr.bank. Zajęcie rachunku bankowego następuje więc w praktyce w chwili wydania właściwej komendy w systemie teleinformatycznym przez pracownika organu egzekucyjnego. Tym samym bank uzyskuje informacje zarówno o zastosowaniu środka egzekucyjnego, jak i o toczącym się postępowaniu egzekucyjnym.

Inaczej kwestia ta wygląda z perspektywy zobowiązanego. O toczącym się wobec niego postępowaniu egzekucyjnym dowiaduje się bowiem z odpisu tytułu wykonawczego, doręczanego mu drogą tradycyjną — zazwyczaj przez operatora 
pocztowego. Co więcej, przepisy ustawy egzekucyjnej dopuszczają możliwość doręczenia odpisu tytułu wykonawczego jednocześnie z odpisem zawiadomienia skierowanego do banku o zakazie wypłaty zajętej kwoty z rachunku bankowego bez zgody organu egzekucyjnego, nawet w jednej przesyłce (art. $80 \S 3$, art. 26 $\S 5$ pkt 2 u.p.e.a.), co jest stałą praktyką przyjętą w organach egzekucyjnych. Różnica sposobów doręczeń doprowadza do tego, że w dniu wszczęcia postępowania egzekucyjnego lub egzekucji ze wszystkimi jej skutkami, czyli między innymi wstrzymaniem przez bank wszelkich wypłat z zajętego rachunku (art. 86a $\S 1$ u.p.e.a.) z zastrzeżeniem wyjątków, o których była mowa wcześniej, zobowiązany nie ma realnej możliwości uzyskania od organu egzekucyjnego informacji o tym. Dowiaduje się on częstokroć o toczącym się wobec niego postępowaniu wykonawczym przez informację z banku lub fakty, takie jak niemożność wypłaty pieniędzy, zapłaty za zakupy, spłaty raty kredytu, uregulowania płatności. Co więcej, zajęcie takie ma częstokroć negatywny wpływ na ocenę zdolności kredytowej.

Przekaźnikiem informacji z banku są najczęściej usługi tak zwanej bankowości elektronicznej. Wówczas po zalogowaniu na swój profil klient banku dostrzega informację o zajęciu rachunku bankowego. Zazwyczaj nie wie jednak, jaki organ egzekucyjny go dokonał. Może skierować takie zapytanie do banku. Praktyka pokazuje też, że zobowiązani poszukują organu egzekucyjnego samodzielnie. Udają się do siedzib organów, które mogły zastosować środek egzekucyjny, i pytają, czy toczy się postępowanie egzekucyjne w ich sprawie. Są zdezorientowani. Sytuacja taka może wydawać się kuriozalna, ale nie są to pojedyncze przypadki. Niekiedy jedynie doświadczenie zawodowe pracowników organów egzekucyjnych umożliwia wywnioskowanie, na podstawie sygnatury zajęcia widniejącej w systemie bankowości elektronicznej, który organ mógł zastosować środek egzekucyjny.

Pozyskiwanie informacji nierzadko wywołuje skrajne emocje wśród zobowiązanych. Praktyce znane są przypadki nieograniczania się do wniesienia środków prawnych przysługujących w administracyjnym postępowaniu egzekucyjnym. Zobowiązani często decydują się na zawiadomienie prokuratury, złożenie na policję doniesienia o nieuprawnionym zaborze mienia czy zwrócenie się o pomoc do mediów. Obywatel nie darzy wówczas zaufaniem ani szacunkiem władzy publicznej. Przede wszystkim ze względu na to, że tkwi w przekonaniu o „dokonaniu grabieży" jego pieniędzy. Pejoratywne odczucia potęguje kolejność działań — najpierw rzeczywiste zajęcie i zablokowanie określonych środków na rachunku bankowym, a następnie doręczenie pism, w których znajduje się informacja, kto i z jakiego powodu to uczynił z pouczeniem, że zobowiązanemu przysługują środki prawne, które umożliwią mu obronę swoich racji. Z punktu widzenia zobowiązanego obrona ta może nastąpić jednak już po fakcie nie tylko zajęcia rachunku bankowego z wszelkimi tego konsekwencjami, ale niekiedy nawet przekazania środków zgromadzonych na rachunku do organu egzekucyjnego.

Obowiązkiem banku jest przekazanie zajętej kwoty organowi egzekucyjnemu na pokrycie egzekwowanej należności. Termin na wykonanie tej operacji ustawo- 
dawca określił słowami: „niezwłocznie po upływie 7 dni od dnia doręczenia zawiadomienia", co oznacza, że wprawdzie zajęcie rachunku bankowego dokonane jest $\mathrm{z}$ chwilą doręczenia bankowi zawiadomienia o zajęciu ze skutkami, o których mowa w art. 86a u.p.e.a. w związku z art. 81 § 4 i 5 u.p.e.a. i art. 54 pr.bank., lecz środki nie mogą być przekazane przed upływem 7 dni od dnia doręczenia bankowi zawiadomienia o zajęciu. Dla zobowiązanych oznacza to, że środki na rachunku bankowym będą zablokowane przez co najmniej $7 \mathrm{dni}$. Jest to dla nich często niekorzystna sytuacja, stąd chcieliby przyspieszenia takiej operacji. Siedmiodniowy termin oczekiwania na możliwość przekazania przez bank środków nie zawsze był wymagany przez przepisy prawne. Obowiązuje od 9 lipca 2018 roku ${ }^{27}$, a uzasadnieniem wprowadzenia tej konstrukcji było zapewnienie zobowiązanemu możliwości skorzystania z przysługujących mu środków prawnych ${ }^{28}$. Należy wspomnieć, że motyw ten dotyczył przede wszystkim sądowego postępowania egzekucyjnego. Zmiana przepisu w administracyjnym postępowaniu egzekucyjnym została podyktowana głównie koniecznością ujednolicenia procedur. Przedstawione rozwiązanie, choć z jednej strony zasługuje na aprobatę z przyczyn opisanych w uzasadnieniu projektu zmian, to $\mathrm{z}$ drugiej strony przyczynia się do wydłużania samej egzekucji. Poza tym przy praktyce doręczania zobowiązanemu odpisu tytułu wykonawczego razem z odpisem zawiadomienia o zajęciu w jednej przesyłce, przy uwzględnieniu czasu potrzebnego na doręczenie, który wydłuża się niekiedy o czas na odebranie przesyłki w wypadku pozostawienia tak zwanego awiza (art. 44 k.p.a.), oficjalna wiadomość o możliwości wniesienia środków prawnych dociera do zobowiązanego niejednokrotnie już po upływie 7 dni od dnia zajęcia rachunku bankowego, a więc i po przekazaniu środków przez bank. Obrona zobowiązanego przybiera więc następczy charakter. Co więcej, nawet gdyby zobowiązany wniósł środki prawne, które zawieszają postępowanie egzekucyjne (na przykład zarzut - zob. art. $35 \S 1$ u.p.e.a.), to i tak nie spowoduje to „uwolnienia” rachunku bankowego, bowiem: „W przypadku zawieszenia postępowania egzekucyjnego pozostają w mocy dokonane czynności egzekucyjne". W egzekucji z rachunku bankowego wprowadzony został jednak wyjątek: „w okresie zawieszenia z przyczyn określonych $\mathrm{w}$ art. $56 \S 1$ pkt 1 i 4 u.p.e.a. mogą być dokonywane, za zgodą organu egzekucyjnego, wypłaty z rachunków bankowych zobowiązanego po przedstawieniu przez niego dokumentów świadczących o konieczności poniesienia danych wydatków. Wyrażenie zgody na wypłatę z rachunku bankowego pozostaje w zakresie uznania organu egzekucyjnego" ${ }^{29}$. Wprawdzie możliwe jest

27 Wprowadzony art. 3 ustawy z dnia 13 kwietnia 2018 roku o zmianie ustawy - Kodeks cywilny oraz niektórych innych ustaw, Dz.U. poz. 1104.

${ }_{28}$ Uzasadnienie rządowego projektu ustawy o zmianie ustawy - Kodeks cywilny oraz niektórych innych ustaw, druk nr 2216 z dnia 22 stycznia 2018 roku, http://www.sejm.gov.pl/Sejm8. nsf/druk.xsp?nr=2216 (dostęp: 19.10.2020).

29 P. Pietrasz, art. 58, [w:] Ustawa o postępowaniu egzekucyjnym w administracji. Komentarz, red. D.R. Kijowski, LEX 2015 (dostęp: 9.10.2020). 
uchylenie dokonanych czynności egzekucyjnych, ale wymaga to spełnienia przesłanek, o których mowa w art. 58 u.p.e.a. oraz czasu na procedowanie w sprawie właściwego wniosku. Zastanawia więc, czy wprowadzenie opisanego rozwiązania miało sens? Mając na względzie doświadczenia praktyczne, trzeba wskazać, że konieczność odczekania z przekazaniem zajętej kwoty nie pozostaje bezcelowa. Jeżeli bowiem zobowiązany zdecyduje się na dokonanie wpłaty do organu egzekucyjnego przed zrealizowaniem zajęcia przez bank, to wówczas organ egzekucyjny może dokonać uchylenia zajęcia, wysyłając stosowny komunikat do banku w systemie teleinformatycznym. Zapłata organowi egzekucyjnemu nie jest egzekucją z pieniędzy (art. 67e $\S 2$ u.p.e.a.). Zobowiązanym zależy niekiedy na takim rozwiązaniu, zwłaszcza przy małych zaległościach, kiedy ich wyegzekwowanie jest mniejszą dolegliwością niż na przykład utrata zdolności kredytowej. Warto jeszcze wspomnieć, że banki dopuszczają możliwość wcześniejszego przekazania środków na rzecz zajęcia, pod warunkiem złożenia odpowiedniego oświadczenia przez klienta ${ }^{30}$.

Rozbieżność czasowa między rzeczywistym uzyskaniem informacji na temat zajęcia rachunku bankowego a doręczeniem zobowiązanemu odpisu tytułu wykonawczego oraz odpisu zawiadomienia niesie kolejne, niekiedy dotkliwe konsekwencje. Doniosłość prawną przyznaje się czynności doręczenia wymienionych pism zobowiązanemu. Od tej daty liczy się choćby terminy na wniesienie środków prawnych. Dobrym przykładem jest tutaj zarzut.

\section{KONSEKWENCJE ASYMETRII INFORMACJI NA PRZYKŁADZIE ZARZUTU W ADMINISTRACYJNYM POSTĘPOWANIU EGZEKUCYJNYM}

Zarzut ustanowiono w art. $27 \S 1$ pkt 9 u.p.e.a. Jest on środkiem prawnym służącym ochronie zobowiązanego $\mathrm{w}$ toku całego postępowania egzekucyjnego, nawet po zakończeniu egzekucji administracyjnej. Granice jego stosowania wyznaczane są legitymacją oraz terminem na jego wniesienie (art. $33 \S 5$ u.p.e.a.), taksatywnie wymienionymi podstawami (art. $33 \S 2$ u.p.e.a.) oraz niedopuszczalnością związaną z zakazem wielokrotnego orzekania przez różne podmioty o jego zasadności (art. $34 \S 2$ pkt 3 lit. a u.p.e.a.).

Maksymalne zawite terminy, których niedochowanie powoduje nieważność czynności prawnej, jaką jest wniesienie zarzutów, określa art. $33 \S 5$ u.p.e.a. ${ }^{31}$ Zgodnie z art. 57 § 1 k.p.a. obliczanie terminu rozpoczyna się od pewnego zdarzenia. Ustawa o postępowaniu egzekucyjnym w administracji nie wskazuje przy zarzucie wprost tego momentu. Odniesienie do początkowego terminu na wnie-

30 Zob. https://www.santander.pl/bank-porad/zajecia-egzekucyjne (dostęp: 26.10.2020).

31 Zob. wyrok NSA z dnia 7 listopada 2014 r., II FSK 1034/13, LEX nr 1598292. 
sienie zarzutu można odnaleźć w art. $27 \S 1$ pkt 9 u.p.e.a. oraz art. $35 \S 1$ u.p.e.a. Pierwsza regulacja ma specyficzny charakter, ponieważ jest $w$ istocie przepisem określającym warunki formalne, jakie powinien spełniać tytuł wykonawczy oraz dodatkowo mówi o prawie do wniesienia przez zobowiązanego do wierzyciela, za pośrednictwem organu egzekucyjnego, zarzutów w sprawie prowadzenia postępowania egzekucyjnego. Druga regulacja wyznacza moc prawną zarzutów. Obydwie posługują się sformułowaniem: „,nie później niż w terminie 7 dni od dnia doręczenia odpisu tytułu wykonawczego". Wskazuje to, że zdarzeniem, od którego należy liczyć termin na wniesienie zarzutu, jest dzień doręczenia zobowiązanemu odpisu tytułu wykonawczego, czyli z założenia pierwsza czynność organu egzekucyjnego skierowana na zewnątrz - wobec zobowiązanego. W tym miejscu ujawnia się specyfika związana ze wszczęciem postępowania egzekucyjnego, jednakże odmienna dla zobowiązanego i organu egzekucyjnego/wierzyciela. Ze względu na jednoznaczne brzmienie art. 26 u.p.e.a. należy uznać, że wszczęcie postępowania egzekucyjnego i egzekucji następuje wobec każdego podmiotu w momencie tam wskazanym. Nie ma więc potrzeby odwoływania się w tym zakresie do przepisów k.p.a. Nie znajduje zastosowania zasada, zgodnie z którą datą wszczęcia postępowania administracyjnego jest pierwsza czynność wobec strony, zatem zawiadomienie o wszczęciu postępowania (art. $61 \S 4$ k.p.a.) $)^{32}$. Wprawdzie uznaje się, że doręczenie zobowiązanemu odpisu/wydruku tytułu wykonawczego jest swoistym zawiadomieniem o wszczęciu postępowania egzekucyjnego, pełniąc funkcję podobną do zawiadomienia o wszczęciu postępowania, o którym mowa art. $61 \S 4$ k.p.a. ${ }^{33}$, jednak nie można uznać, że wszczęcie postępowania egzekucyjnego wobec zobowiązanego następuje $\mathrm{w}$ innym momencie niż wskazany w art. 26 u.p.e.a., a konkretnie w chwili doręczenia mu odpisu/wydruku tytułu wykonawczego. O ile moment wszczęcia postępowania i egzekucji administracyjnej jest taki sam dla wszystkich, o tyle wiedzę o tym poszczególne podmioty uzyskują niejednokrotnie w różnym czasie. Ta dychotomia doprowadziła do poważnych wątpliwości, czy zarzut może być wniesiony już przed doręczeniem zobowiązanemu odpisu tytułu wykonawczego? Formalnie postępowanie egzekucyjne już się toczy, jednakże organ egzekucyjny nie podjął jeszcze czynności urzędowych, o których powiadomiłby zobowiązanego. Ograniczenie analizy do przepisów ogólnych u.p.e.a. doprowadzi do wniosku, zgodnie z którym ten ostatni nie powinien dysponować wiedzą na temat toczącego się postępowania. Zaznajomienie się z przepisami szczególnymi z zakresu stosowania konkretnych środków egzekucyjnych unaocznia, że w istocie może być inaczej.

Gdy pismo zobowiązanego, w którym podnosi naruszenie mieszczące się w katalogu zarzutów (art. $33 \S 2$ u.p.e.a.) wpłynie do organu egzekucyjnego przed

32 B. Adamiak, art. 61, [w:] B. Adamiak, J. Borkowski, Kodeks postępowania administracyjnego. Komentarz, Legalis 2021 (dostęp: 30.04.2021).

33 M. Masternak, art. 32, [w:] M. Masternak, art. 32, [w:] Postępowanie egzekucyjne $w$ administracji. Komentarz, red. R. Hauser, M. Wierzbowski, Legalis 2021 (dostęp: 30.04.2021). 
doręczeniem mu odpisu tytułu wykonawczego, organ egzekucyjny staje przed dylematem orzeczniczym. Po pierwsze, jakie daty ma wziąć pod uwagę przy badaniu dopuszczalności wniesienia zarzutów — datę nadania zarzutu w placówce pocztowej czy datę wpływu pisma do organu administracji publicznej? Po drugie, czy dopuszczalne jest merytoryczne rozpatrzenie zarzutów?

Potrzeba udzielenia odpowiedzi na pierwsze pytanie nabiera sensu przy przyjęciu założenia o niedopuszczalności wniesienia zarzutów przed dniem doręczenia zobowiązanemu odpisu tytułu wykonawczego. Zgodnie z art. $61 \S 3$ k.p.a.: „Datą wszczęcia postępowania na żądanie strony jest dzień doręczenia żądania organowi administracji publicznej”. „Datą wszczęcia postępowania na żądanie strony wniesione drogą elektroniczną jest dzień wprowadzenia żądania do systemu teleinformatycznego organu administracji publicznej” (§ 3a). Do ustalenia daty wszczęcia postępowania administracyjnego miarodajna jest data złożenia wniosku do urzędu, a nie data jego sporządzenia przez stronę ${ }^{34}$. Przepis art. 57 § 5 k.p.a. określa ustawowe warunki zachowania terminu. „Powyższe rozwiązanie pozwala na uznanie, że czynność nastąpiła bez naruszenia terminu, mimo że faktycznie nie doszło do wypełnienia zdarzenia, od którego dana norma prawna uzależniała zachowanie terminu" 35 . Artykuł $57 \S 5$ k.p.a. pozwala na zachowanie terminu, jeżeli pismo zostało wysłane/nadane/złożone ,przed jego upływem”. Według słownika języka polskiego zwrot ten w odniesieniu do odcinków czasu oznacza „minięcie czasu lub zdarzeń trwających w czasie"36. Dokonując literalnej interpretacji tego przepisu, należy uznać, że wskazuje on na stosowanie instytucji zachowania terminu do końcowej daty okresu na dokonanie określonej czynności prawnej, w tym przypadku wniesienia zarzutu. Ma to na celu uchronić stronę od negatywnych konsekwencji, gdyby nie zdążyła złożyć pisma osobiście w siedzibie organu administracji publicznej. Sformułowanie ,przed upływem terminu” nie oznacza „przed rozpoczęciem biegu terminu”. Stąd należy zająć stanowisko, że przy rozstrzyganiu o przedwczesności wniesienia zarzutu należy brać pod uwagę termin wpływu zarzutu do organu administracji publicznej. Datą wszczęcia postępowania w sprawie zarzutów jest bowiem dzień doręczenia żądania organowi administracji publicznej, a nie dzień nadania żądania, o którym mowa w art. 57 § 5 k.p.a. Branie pod uwagę wcześniejszej daty nadania zarzutu, a nie późniejszej daty wpływu pisma do organu administracji publicznej, przy przyjęciu stanowiska o niedopuszczalności wniesienia zarzutu przed dniem doręczenia zobowiązanemu odpisu tytułu wykonawczego, ograniczałoby dodatkowo prawo zobowiązanego do obrony przed egzekucją.

Interpretacja sformułowania: „w terminie $\mathrm{X}$ dni od dnia doręczenia zobowiązanemu tytułu wykonawczego" wywołuje jeszcze więcej wątpliwości. Wedle poglądów o konieczności jego literalnego odczytywania, gdy bierze się pod uwa-

34 Wyrok NSA z dnia 14 lipca 2006 r., II OSK 980/05, Legalis nr 287732.

35 R. Stankiewicz, art. 57, [w:] Kodeks postepowania administracyjnego. Komentarz, red. M. Wierzbowski, A. Wiktorowska, Legalis 2019 (dostęp: 23.10.2020).

36 Stownik języka polskiego PWN, https://sjp.pwn.pl/szukaj/upływ.html (dostęp: 26.11.2019). 
gę regułę, zgodnie z którą „Jeżeli początkiem terminu określonego w dniach jest pewne zdarzenie, przy obliczaniu tego terminu nie uwzględnia się dnia, w którym zdarzenie nastąpiło" (art. 57 § 1 k.p.a.) należałoby uznać, że zarzutu nie można wnieść w dniu, w którym nastąpiło doręczenie zobowiązanemu odpisu tytułu wykonawczego ${ }^{37}$. Opowiadając się za funkcjonalną wykładnią przepisów, możliwość taką należy dopuścić ${ }^{38}$. Z przytoczonych treści widać, jak wiele wątpliwości powstaje w kwestii początkowej daty na złożenie zarzutu. W gruncie rzeczy są one niekorzystne dla zobowiązanego, co skłania do zastanowienia się nad zastosowaniem wykładni rozstrzygającej na korzyść zobowiązanego.

Odpowiadając na drugie pytanie, należy wskazać, że przez wiele lat zdawało się przeważać stanowisko, wedle którego zarzut, o którym mowa w art. 33 $\S 1$ u.p.e.a., wniesiony przed terminem doręczenia zobowiązanemu odpisu tytułu wykonawczego, nie może odnieść skutku, podobnie jak wniesiony po terminie ${ }^{39}$. W orzecznictwie sądowoadministracyjnym pojawiły się jednak odmienne głosy. Wojewódzki Sąd Administracyjny w Warszawie wywiódł, że

Niewskazanie przez ustawodawcę w art. 27 § 1 pkt 9 u.p.e.a. daty, od której należy liczyć siedmiodniowy termin do wniesienia zarzutów, oraz okoliczność, że sformułowanie przez zobowiązanego zarzutów wskazanych $\mathrm{w}$ art. $33 \S 1$ pkt 1-10 u.p.e.a. możliwe jest także przed doręczeniem mu tytułu wykonawczego, uzasadnia twierdzenie, że termin wskazany w powołanym przepisie upływa najpóźniej po siedmiu dniach od doręczenia zobowiązanemu tytułu wykonawczego. Oznacza to, że w przypadku wniesienia zarzutów przed doręczeniem zobowiązanemu tytułu wykonawczego, niezasadne jest twierdzenie, że zarzuty te są przedwczesne ${ }^{40}$.

Nieuregulowanie wyraźne sposobu liczenia początkowego terminu do wniesienia zarzutów jest niewątpliwie rozwiązaniem wadliwym. Negatywna ocena jakości legislacji w tym zakresie nie uchroniła jednak przed koniecznością stosowania przepisów dotyczących zarzutu oraz oceny dopuszczalności tego środka zaskarżenia. Nie odrzucając z góry żadnego z przedstawionych poglądów, należy zastanowić się nad motywami oraz konsekwencjami przyjętych rozwiązań.

37 Zob. wyrok WSA w Poznaniu z dnia 7 listopada 2018 r., IV SA/Po 661/18, LEX nr 2586434.

38 Zob. W. Piątek, Zrzeczenie się odwołania $w$ ogólnym postępowaniu administracyjnym, ZNSA 2019, nr 5 (86), s. 51; P. Gacek, Zasada dwuinstancyjnego postępowania a zrzeczenie się prawa do wniesienia odwołania, „Przegląd Prawa Publicznego” 2018, nr 10, s. 51.

39 Wyrok WSA w Gliwicach z dnia 14 marca 2019 r., I SA/Gl 1255/18, LEX nr 2636788; wyrok WSA w Bydgoszczy z dnia 25 sierpnia 2008 r., I SA/Bd 104/08, LEX nr 471294; wyrok NSA z dnia 7 listopada 2014 r., II FSK 1034/13, LEX nr 1598292; wyrok WSA w Lublinie z dnia 19 kwietnia 2018 r., II SA/Lu 142/18, LEX nr 2506471; wyrok WSA w Poznaniu z dnia 17 października 2018 r., II SA/Po 546/18, LEX nr 2578542; R. Hauser, Z. Leoński, art. 33, [w:] Postepowanie egzekucyjne $w$ administracji, Komentarz, red. R. Hauser, A. Skoczylas, Warszawa 2011, s. 195; C. Kulesza, art. 33, [w:] Ustawa o postepowaniu egzekucyjnym $w$ administracji. Komentarz, red. D.R. Kijowski, LEX 2015 (dostęp: 25.10.2020).

40 Wyrok WSA w Warszawie z dnia 20 marca 2019 r., III SA/Wa 1037/18, LEX nr 2642695; zob. wyrok WSA w Warszawie z dnia 27 września 2018 r., III SA/Wa 3930/17, LEX nr 2570865. 
Za przyjęciem wykładni, wedle której wniesienie zarzutu przed terminem doręczenia zobowiązanemu odpisu tytułu wykonawczego jest niedopuszczalne, przemawia przede wszystkim argument mówiący o tym, że przestrzeganie ustawowego terminu do wniesienia środka zaskarżenia jest gwarancją realizacji zasady pewności prawa i nie może być interpretowane w taki sposób, który skracałby lub wydłużał ustawowe terminy do dokonania czynności procesowej ${ }^{41}$. Należy też zauważyć, że w większości przypadków zobowiązany, któremu odmówiono merytorycznego rozpatrzenia zarzutów ze względu na ich przedwczesne wniesienie, nie zostaje pozbawiony ochrony. Zarzuty można wnieść nawet po wyegzekwowaniu obowiązku. Jedynie ich moc prawna różni się w zależności od momentu ich wniesienia (art. $35 \S 1$ u.p.e.a. $)^{42}$. Można również wnioskować, że skoro pouczenie o możliwości zgłoszenia zarzutów jest koniecznym elementem składowym doręczanego zobowiązanemu odpisu tytułu wykonawczego, to gdy brakuje wyraźnej regulacji ustawodawcy, trudno byłoby przyjąć inny termin do wniesienia zarzutów aniżeli liczony od daty doręczenia zobowiązanemu tego dokumentu urzędowego, w którym zamieszczone zostało stosowne pouczenie ${ }^{43}$. Na poparcie słuszności tej wykładni można powołać posiłkowo tak zwany argument $\mathrm{z}$ ugruntowanego orzecznictwa. Wielokrotnie opowiadały się za nim zarówno Naczelny Sąd Administracyjny ${ }^{44}$, jak i wojewódzkie sądy administracyjne ${ }^{45}$, a także przedstawiciele doktryny ${ }^{46}$.

Na poparcie stanowiska opowiadającego się za dopuszczeniem wniesienia zarzutów przed doręczeniem zobowiązanemu odpisu tytułu wykonawczego można odnaleźć mnogość argumentów ${ }^{47}$.

Pierwsze, co rzuca się w oczy podczas analizy tekstu prawnego, to brak sztywnego określenia daty, od której należy wnosić zarzut (art. $27 \S 1$ pkt 9 u.p.e.a.). Trzeba zauważyć, że regulacja art. $27 \S 1$ pkt 9 u.p.e.a. przede wszystkim nakłada obowiązek informacyjny na organ egzekucyjny, mający służyć zobowiązanemu i gwarantować, że poweźmie on wiedzę o możliwych środkach ochrony. Mając na względzie wartości konstytucyjne i odpowiadające im naczelne zasady procesowe, takie jak choćby zasada zaufania do organów państwa, nie sposób z tego przepisu wyprowadzać normy prawnej limitującej prawa zobowiązanego, która nie wynika wprost z językowego odczytania wspomnianego przepisu. Zasada na-

41 Wyrok WSA w Poznaniu z dnia 17 października 2018 r., II SA/Po 546/18, LEX nr 2578542; wyrok WSA w Gliwicach z dnia 14 marca 2019 r., I SA/Gl 1255/18, LEX nr 2636788.

${ }^{42}$ Inaczej było przed 30 lipca 2020 roku, gdy termin na wniesienie zarzutów wynosił 7 dni od dnia doręczenia zobowiązanemu odpisu tytułu wykonawczego.

43 Wyrok WSA w Gdańsku z dnia 25 września 2018 r. II SA/Gd 329/18, LEX nr 2575998.

44 Wyrok NSA z dnia 7 listopada 2014 r. II FSK 1034/13, LEX nr 1598292.

45 Zob. wyrok WSA w Gliwicach z dnia 14 marca 2019 r. I SA/G1 1255/18, LEX nr 2636788; wyrok WSA w Bydgoszczy z dnia 25 sierpnia 2008 r., I SA/Bd 104/08, LEX nr 471294; wyrok WSA w Lublinie z dnia 19 kwietnia 2018 r., II SA/Lu 142/18, LEX nr 2506471; wyrok WSA w Poznaniu z dnia 17 października 2018 r., II SA/Po 546/18, LEX nr 2578542.

46 R. Hauser, Z. Leoński, op. cit., s 195; C. Kulesza, op. cit.

47 Zob. wyrok NSA z dnia 29 maja 2019 r., I FSK 282/19, LEX nr 2703397. 
kazująca interpretację normy prawnej, wobec której pozostają niedające się usunąć wątpliwości na korzyść strony/zobowiązanego, nie pozwala na interpretację przepisu art. $27 \S 1$ pkt 9 u.p.e.a. w sposób zmniejszający spektrum merytorycznej ochrony zobowiązanego $\mathrm{w}$ administracyjnym postępowaniu egzekucyjnym.

Podsumowując, należy uznać, że zarzuty w sprawie prowadzenia postępowania egzekucyjnego mogą być składane od momentu wszczęcia postępowania egzekucyjnego, a nie egzekucji administracyjnej. Nie jest przy tym istotne, z jakiego źródła zobowiązany dowiedział się o prowadzonym wobec niego postępowaniu egzekucyjnym. O przedwczesnym wniesieniu zarzutów można mówić wówczas, gdyby zostały wniesione przed wszczęciem postępowania egzekucyjnego. Mogłoby do tego dojść, albowiem bodźcem dla zobowiązanego mogłoby być doręczenie upomnienia zawierającego wezwanie do wykonania obowiązku z zagrożeniem skierowania sprawy na drogę postępowania egzekucyjnego (art. 15 u.p.e.a.). Zapatrywanie ograniczające czasowo prawo wniesienia zarzutów w postępowaniu egzekucyjnym przez wskazanie jako daty początkowej dnia doręczenia odpisu tytułu wykonawczego jest więc akontekstowe w tym sensie, że nie uwzględnia ani pojemnej formuły językowej wspomnianego przepisu, ani celu, któremu służy pouczenie o prawie zgłoszenia tychże zarzutów. $Z$ obowiązku nałożonego na organ egzekucyjny wyprowadza się tu normę prawną limitującą prawa zobowiązanego, która nie wynika wprost z językowego odczytania tegoż przepisu ${ }^{48}$. Mając dodatkowo na względzie nowelizację ustawy egzekucyjnej, która weszła w życie z dniem 30 lipca 2020 roku i wydłużyła termin na wniesienie zarzutów, należy opowiedzieć się za wykładnią dopuszczającą wniesienie zarzutów przed dniem doręczenia zobowiązanemu odpisu tytułu wykonawczego. Gdyby nawet organ odmówił wszczęcia postępowania ze względu na przedwczesne wniesienie zarzutów, to zobowiązany najprawdopodobniej wniósłby je ponownie, już po doręczeniu odpisu tytułu wykonawczego. Wierzyciel i tak musiałby je więc merytorycznie rozpatrzyć. Negatywną konsekwencją wniesienia zarzutów po upływie terminu 7 dni od dnia doręczenia odpisu tytułu wykonawczego mógłby być w obecnym stanie prawnym brak skutku zawieszenia postępowania egzekucyjnego (art. 35 $\S 1$ a contrario u.p.e.a.). Stanowiłoby to więc negatywną konsekwencję dla zobowiązanego, co z przyczyn, o których wspomniano, skłania do przyjęcia wykładni korzystniejszej dla zobowiązanego.

\section{PODSUMOWANIE}

Przyczyna asymetrii informacji $\mathrm{w}$ administracyjnym postępowaniu egzekucyjnym na przykładzie egzekucji wierzytelności z rachunku bankowego tkwi przede wszystkim w konstrukcji techniczno-procesowych czynności postępowa-

48 Ibidem. 
nia, jakimi są doręczenia. Na skutek elektronizacji działalności administracji publicznej wprowadzono obowiązek komunikowania się organów egzekucyjnych z bankami przez wykorzystanie systemów teleinformatycznych, co umożliwia natychmiastową wymianę wiadomości. Bez zmian pozostał natomiast sposób doręczania pism zobowiązanemu, nadal wykorzystujący formę tradycyjną, wiążącą się z opóźnieniami komunikacyjnymi. Obecnie trudno sobie wyobrazić działania organów egzekucyjnych bez wykorzystania dobrodziejstw techniki w tym zakresie. Przy skali dokonywanych zajęć egzekucyjnych informatyzacja pozwoliła na znacznie sprawniejsze działanie i zwiększyła skuteczność egzekucji administracyjnej przy mniejszym nakładzie pracy ludzkiej. Gdzieś w tle pozostał jednak zobowiązany, który częstokroć nie kryje oburzenia z obowiązującego sposobu postępowania. Przyjmując paradygmat, zgodnie z którym jednostka stoi w centrum zainteresowania administratywistyki, nie można jednak bezgranicznie interpretować przepisów na jej korzyść. Nie można również widzieć wyłącznie interesu fiskalnego organów egzekucyjnych i wierzycieli. W celu udzielenia odpowiedzi na pytanie, czy obowiązujące przepisy są właściwie skonstruowane, należy przede wszystkim zastanowić się, czy organ egzekucyjny zaskakuje zobowiązanego zastosowaniem środka egzekucyjnego. Należy uznać, że nie. Działania informacyjne podejmowane są bowiem już na etapie jurysdykcyjnym. Następnie może dojść do zastosowania tak zwanej egzekucji miękkiej, pod której pojęciem rozumie się działania informacyjne wierzyciela (art. $6 \S 1$ b u.p.e.a.). Obligatoryjnie dochodzi do przesłania zobowiązanemu upomnienia. Właśnie ono jest już ostatnim ostrzeżeniem, że w razie niewykonania obowiązku zostaną zastosowane środki egzekucyjne. Nie można więc wyprowadzić wniosku, że zobowiązany nie mógł dostrzec widma zbliżającej się egzekucji.

Konstrukcję przejawiającą się w tym, że zobowiązany dowiaduje się w istocie już o zajętym rachunku bankowym, a nie ostrzeżeniu, że za chwilę zostanie on zajęty, należy postrzegać z punktu widzenia celu egzekucji, czyli doprowadzenia do skutecznego zaspokojenia wierzyciela. Na tym etapie zobowiązany nie może wiedzieć, który środek egzekucyjny zastosuje organ. Poinformowanie go najpierw o zamiarze zastosowania środka egzekucyjnego tworzyłoby oczywistą wskazówkę, jakich czynności dokonać, aby udaremnić egzekucję (na przykład przez pozorne wyzbycie się majątku). W świetle przedstawionych uwag obowiązującą obecnie konstrukcję zajęcia wierzytelności z rachunku bankowego należy zaaprobować. Zobowiązany w sposób wystarczający uzyskuje informację o groźbie zastosowania egzekucji.

Problem pojawia się jednak wówczas, gdy dochodzi do błędnego zastosowania egzekucji, na przykład gdy zobowiązany nie otrzyma upomnienia albo wprawdzie je otrzyma, ale że nie może go zaskarżyć, to pozostanie mu jedynie czekać na zastosowanie wobec niego środków egzekucyjnych. Oczywiście nie jest zabronione skierowanie pisma wyjaśniającego do wierzyciela, który ma szansę odnaleźć błędy swojego działania, jednakże na tym etapie jest to bardzo słaby 
środek obrony. Jeżeli wierzyciel skieruje tytuł wykonawczy do egzekucji, to zobowiązany musi liczyć się z tym, że obronę swoich praw będzie mógł podjąć dopiero po zajęciu wierzytelności z rachunku bankowego. Ze względu na czas potrzebny na procedowanie do wyegzekwowania należności dochodzi często jeszcze przed podjęciem rozstrzygnięcia w sprawie zainicjowanej wniesieniem środka zaskarżenia. Również dopuszczanie możliwości wniesienia zarzutów przed dniem doręczenia zobowiązanemu odpisu tytułu wykonawczego nie zmienia tego faktu. Co więcej, nawet umorzenie postępowania egzekucyjnego, po przekazaniu zajętej kwoty, nie zawsze gwarantuje jej zwrot. Należy pamiętać, że „kwoty ściągnięte w wyniku bezprawnej egzekucji muszą być uznane za »nienależnie zapłacony podatek «, o którym mowa w art. $72 \S 1$ pkt 1 tej ustawy [o.p. $\left.{ }^{49}\right]^{\prime 50}$. Kwoty te są więc nadpłatą, która wraz $\mathrm{z}$ jej oprocentowaniem podlega zaliczeniu z urzędu na poczet zaległości podatkowych wraz z odsetkami za zwłokę, odsetek za zwłokę od nieuregulowanych w terminie zaliczek na podatek, kosztów upomnienia oraz bieżących zobowiązań podatkowych, a w razie ich braku — podlegają zwrotowi z urzędu, chyba że podatnik złoży wniosek o zaliczenie nadpłaty w całości lub w części na poczet przyszłych zobowiązań podatkowych (art. 76 § 1 o.p.).

W tym miejscu znów pojawia się refleksja nad bezlitosnym charakterem przepisów postępowania egzekucyjnego i ordynacji podatkowej. Zważając na charakter postępowania egzekucyjnego, warto być może dopuścić myśl, że jego regulacje mają wywierać wpływ nie tylko na indywidualnego zobowiązanego, lecz oddziaływać też prewencyjnie na jednostki wykazujące opór wobec ciążących na nich obowiązków.

Ostatnie zdanie podsumowania tego artykułu powinno sprowadzać się do zajęcia konkretnego stanowiska. Jest to jednak trudne, zależy bowiem od konkretnej sprawy. Zestawienie konstrukcji z przypadkiem, gdy egzekucja jest prowadzona bezprawnie prowadzi do wniosku, że zobowiązany powinien mieć realną możliwość obrony swoich praw jeszcze przed faktyczną realizacją środka egzekucyjnego. Rozwiązanie tego problemu wcale nie musi być skomplikowane. Wydaje się, że wystarczyłoby wprowadzić regulację, wedle której środki egzekucyjne mogą być stosowane dopiero po doręczeniu zobowiązanemu odpisu tytułu wykonawczego. Wówczas wiedziałby o toczącym się postępowaniu egzekucyjnym i mógł podjąć środki prawne (na przykład wnieść zarzut, który zawiesiłby postępowanie egzekucyjne, a więc uniemożliwił stosowanie środków egzekucyjnych). Niestety w praktyce doprowadziłoby to do paraliżu egzekucji, gdyż większość zobowiązanych korzystałaby z tego prawa często tylko po to, aby opóźnić lub udaremnić egzekucję. Dlatego zestawienie konstrukcji z przypadkiem, w którym egzekucja jest prowadzona prawidłowo, nie pozwala na zaaprobowanie przedstawionego rozwiązania.

49 Ustawa z dnia 29 sierpnia 1997 roku — Ordynacja podatkowa, tekst jedn. Dz.U. z 2021 r. poz. 1540 ze zm.

50 Wyrok NSA z dnia 24 października 2012 r., II FSK 360/11, LEX nr 1234075. 
Uzależnienie kształtu rozwiązań od hipotetycznie przyjętych założeń o dopuszczalności bądź niedopuszczalności egzekucji pozwala na akademickie rozważania w tym zakresie. Organ egzekucyjny na etapie wszczęcia egzekucji często nie wie, czy nie zajdą podstawy do umorzenia postępowania egzekucyjnego, czy jednak będzie możliwe efektywne jego zakończenie. Dlatego musi zdecydować, czy dać zobowiązanemu szansę na obronę przed zastosowaniem egzekucji z rachunku bankowego, czyli przed przesłaniem do banku zawiadomienia o zajęciu skierować do zobowiązanego odpis tytułu wykonawczego wraz z tak zwanym nieformalnym wezwaniem do zapłaty i dopiero w razie bezskuteczności tych działań zastosować środek egzekucyjny? Czy od razu zastosować środek egzekucyjny? W praktyce więc, jeżeli organowi egzekucyjnemu zobowiązany jest znany z permanentnego unikania egzekucji, to wówczas środek egzekucyjny stosowany jest od razu. Jeżeli natomiast organ spodziewa się, że wystarczy wezwanie do zapłaty, to decyduje się na pierwszy wariant. Uwidacznia się tu znacząca rola pracownika organu egzekucyjnego, który musi zdecydować się na konkretny krok. Poczynione uwagi prowadzą do wniosku, że obecna konstrukcja optymalnie wyważa możliwość podjęcia obrony przez zobowiązanego ze skutecznością egzekucji.

\section{PRACTICAL ASPECTS OF BANK ACCOUNT SEIZURE IN ADMINISTRATIVE ENFORCEMENT PROCEEDINGS}

\section{Summary}

The aim of this MA thesis is to present the most commonly chosen mean of execution of monetary obligations - execution against bank accounts. The study discusses a concept of a bank account, its essence and legal regulation, as well as describes the legal basis of execution against bank accounts. The article analyses enforcement proceedings, legal consequences of the attachment of the debtor's bank account, limitations of execution. In this article, the formal-dogmatic method of working on the issue of enforcing a bank account. The analysis includes questionable issues within both the theoretical and practical field as well as recent doctrinal and judicial achievements. The thesis refers to the legal regulation currently in effect in the scope of the study and indicates adopted amendments which will come into force on 19 February 2021.

Keywords: bank account, the subject of enforcement, execution of the bank account, discontinuance of the proceedings, delivery

\section{BIBLIOGRAFIA}

Adamiak B., art. 61, [w:] B. Adamiak, J. Borkowski, Kodeks postępowania administracyjnego. Komentarz, Legalis 2021.

Gacek P., Zasada dwuinstancyjnego postepowania a zrzeczenie się prawa do wniesienia odwołania, „Przegląd Prawa Publicznego” 2018, nr 10. 
Hauser R., Leoński Z., art. 33, [w:] Postępowanie egzekucyjne w administracji. Komentarz, red. R. Hauser, A. Skoczylas, Warszawa 2011.

Karpiuk M., Egzekucja administracyjna z rachunków bankowych, „Glosa” 2014, nr 4.

Klat-Wertelecka L., Egzekucja administracyjna w praktyce, Gdańsk 2013.

Klat-Wertelecka L., Pojęcie postępowania egzekucyjnego w administracji a pojęcie egzekucji administracyjnej, „Opolskie Studia Administracyjno-Prawne” 2011, z. 9.

Kulesza C., art. 33, [w:] Ustawa o postępowaniu egzekucyjnym $w$ administracji. Komentarz, red. D. R. Kijowski, LEX 2015.

Masternak M., art. 32, [w:] Postępowanie egzekucyjne w administracji. Komentarz, red. R. Hauser, M. Wierzbowski, Legalis 2021.

Niezbecka E., Egzekucja administracyjna z rachunków bankowych, [w:] System egzekucji administracyjnej, red. J. Niczyporuk, S. Fundowicz, J. Radwanowicz, Lublin 2004.

Piątek W., Skoczylas A., Egzekucja z rachunków bankowych i wkładów oszczędnościowych, [w:] System Prawa Administracyjnego, t. 9. Prawo procesowe administracyjne, red. R. Hauser, Z. Niewiadomski, A. Wróbel, Warszawa 2020.

Piątek W., Zrzeczenie się odwołania w ogólnym postępowaniu administracyjnym, „Zeszyty Naukowe Sądownictwa Administracyjnego" 2019, nr 5 (86).

Pietrasz P., art. 58, [w:] Ustawa o postępowaniu egzekucyjnym $w$ administracji. Komentarz, red. D.R. Kijowski, LEX 2015.

Stownik języka polskiego PWN, https://sjp.pwn.pl/szukaj/upływ.html.

Stankiewicz R., art. 57, [w:] Kodeks postepowania administracyjnego. Komentarz, red. M. Wierzbowski, A. Wiktorowska, Legalis 2019.

Uzasadnienie rządowego projektu ustawy o zmianie ustawy - Kodeks cywilny oraz niektórych innych ustaw, druk $\mathrm{nr} 2216 \mathrm{z}$ dnia 22.01.2018 roku, http://www.sejm.gov.pl/Sejm8.nsf/druk. $\mathrm{xsp}$ ?nr=2216.

Zręda W., Administracyjne zajęcie rachunku bankowego, „Prawo Bankowe” 2002, nr 3.

\section{WYKAZ AKTÓW PRAWNYCH}

Ustawa z dnia 14 czerwca 1960 roku — Kodeks postępowania administracyjnego, tekst jedn. Dz.U. z 2020 r. poz. 256 ze zm.

Ustawa z dnia 17 czerwca 1966 roku o postępowaniu egzekucyjnym w administracji, tekst jedn. Dz.U. z 2020 r. poz. 1427.

Ustawa z dnia 29 sierpnia 1997 r. — Ordynacja podatkowa, tekst jedn. Dz.U. z 2021 r., poz. 1540 ze zm.

Ustawa z dnia 29 sierpnia 1997 roku Prawo bankowe, tekst jedn. Dz.U. z 2019 r. poz. 2357 ze zm.

Ustawa z dnia 13 kwietnia 2018 roku o zmianie ustawy — Kodeks cywilny oraz niektórych innych ustaw, Dz.U. poz. 1104.

Ustawa z dnia 4 lipca 2019 roku o zmianie ustawy o postępowaniu egzekucyjnym w administracji oraz niektórych innych ustaw, Dz.U. z 2019 r. poz. 1553.

Ustawa z dnia 11 września 2019 roku o zmianie ustawy o postępowaniu egzekucyjnym w administracji oraz niektórych innych ustaw, Dz.U. z 2019 r. poz. 2070 ze zm.

\section{WYKAZ ORZECZNICTWA}

Wyrok NSA z dnia 22 grudnia 1999 r., III SA 8330/98, LEX nr 47238.

Wyrok NSA z dnia 14 lipca 2006 r., II OSK 980/05, Legalis nr 287732.

Wyrok NSA z dnia 24 października 2012 r., II FSK 360/11, LEX nr 1234075.

Wyrok NSA z dnia 7 listopada 2014 r., II FSK 1034/13, LEX nr 1598292. 
Wyrok NSA z dnia 31 stycznia 2019 r., II FSK 3034/18, LEX nr 2656931.

Wyrok NSA z dnia 29 maja 2019 r., I FSK 282/19, LEX nr 2703397.

Wyrok SN z dnia 3 marca 2011 r., II UK 307/10, LEX nr 785627.

Wyrok SO w Warszawie z dnia 9 stycznia 2012 r., XVII AmC 375/11, LEX nr 2545366.

Wyrok WSA w Bydgoszczy z dnia 25 sierpnia 2008 r., I SA/Bd 104/08, LEX nr 471294.

Wyrok WSA w Gdańsku z dnia 25 września 2018 r., II SA/Gd 329/18, LEX nr 2575998.

Wyrok WSA w Gliwicach z dnia 14 marca 2019 r., I SA/Gl 1255/18, LEX nr 2636788.

Wyrok WSA w Gorzowie Wielkopolskim z dnia 1 grudnia 2011 r., I SA/Go 1015/11, LEX nr 1133480.

Wyrok WSA w Lublinie z dnia 19 kwietnia 2018 r., II SA/Lu 142/18, LEX nr 2506471.

Wyrok WSA w Poznaniu z dnia 17 października 2018 r., II SA/Po 546/18, LEX nr 2578542.

Wyrok WSA w Poznaniu z dnia 7 listopada 2018 r., IV SA/Po 661/18, LEX nr 2586434.

Wyrok WSA w Warszawie z dnia 19 listopada 2007 r., III SA/Wa 1462/07, LEX nr 494247.

Wyrok WSA w Warszawie z dnia 27 września 2018 r., III SA/Wa 3930/17, LEX nr 2570865.

Wyrok WSA w Warszawie z dnia 20 marca 2019 r., III SA/Wa 1037/18, LEX nr 2642695.

Wyrok WSA w Szczecinie z dnia 4 listopada 2015 r., I SA/Sz 960/15, Legalis nr 1390447. 